\title{
EFFECT OF REMOTE ISCHEMIC PRECONDITIONING ON HEPATIC FUNCTION AFTER $\mathrm{CO}_{2}$ PNEUMOPERITONEUM
}

\section{EFEITO DO PRECONDICIONAMENTO ISQUÊMICO REMOTO NA FUNÇÃO HEPÁTICA APÓS PNEUMOPERITÔNEO COM CO}

Joyce Eunice Freitas Santos ${ }^{1}$, Ítalo Medeiros de Azevedo ${ }^{2}$, Keyla Borges Ferreira Rocha ${ }^{3}$, Aldo Cunha Medeiros ${ }^{4}$

1. Graduate student, Medical School, Federal University of Rio Grande do Norte (UFRN), Natal-RN, Brazil.

2. PhD, Statistician, Department of Surgery, UFRN, Natal- RN, Brazil.

3. PhD, Associate Professor, Department of Pathology, UFRN, Natal- RN, Brazil.

4. PhD, Full Professor, Chairman, Nucleus of Experimental Surgery, UFRN, Natal-RN, Brazil.

Study performed at Department of Surgery, Federal University of Rio Grande do Norte (UFRN), Brazil.

Financial support: CNPq, Grant:311625/2018/5.

Conflicts of interest: None.

Address for correspondence: Department of Surgery, Federal University of do Rio Grande do Norte, Ave. Nilo Peçanha 620, Natal, RN, Brazil.

E-mail: cirurgex.ufrn@gmail.com.

Submitted: nov 25; accepted after revision, nov 25, 2020.

\section{ABSTRACT}

Objective: This study aimed to examine whether remote ischemic preconditioning can influence the effects of pneumoperitoneum with $\mathrm{CO} 2$ on the function and structure of the liver of rodents. Methods: Three groups of 6 Wistar rats each were used. 1) laparotomy group; 2) pneumoperitoneum (30 $\mathrm{min}$ ) group; 3) pneumoperitoneum (30 min) group and remote ischemic preconditioning. Two hours after the surgical procedures, blood was collected to measure aspartate aminotransferase (AST), alanine aminotransferase (ALT), and alkaline phosphatase (ALP). Euthanasia was performed with an overdose of thiopental (100 mg/kg i.p.). Liver tissue samples were collected, processed, stained with $\mathrm{HE}$ and histopathological scores were determined. Values expressed as mean \pm standard deviation were analyzed by the Fischer and Tukey's tests, with significance $p<0.05$. Results: The levels of ALT, AST and ALP in animals in group 2, reaching $74.3 \pm 3.5,62.3 \pm 3.1$ and $172.6 \pm 3.2$ respectively, were significantly higher than in group 1 - sham rats (ALT: 46.2 \pm 3.7 ; AST: $40.5 \pm 6.2$ and ALP: $125.8 \pm 6.4$ ). The group 3 rats had levels of ALT: $68.6 \pm 2.1$; AST: $51.8 \pm 2.7$ and ALP: $144.6 \pm 4.3$ significantly lower 
Effect of remote ischemic preconditioning on hepatic function after $\mathrm{co} 2$ pneumoperitoneum Santos JEF; et al

than group 2. ( $\mathrm{p}<0.01$ ). Histopathological scores revealed that in the laparotomy group (score 3 ) the findings of neutrophil infiltration, sinusoid congestion, degree of necrosis and vacuolization of the cytoplasm were significantly less intense or absent $(p<0.05)$, when compared with the pneumoperitoneum group (score 6) and pneumoperitoneum+remote $\mathrm{I} / \mathrm{R}$ group (score 5). Although the score in the pneumoperitoneum + remote I/R group was lower than in the pneumoperitoneum group, the difference was not significant $(p>0.05)$. Conclusion: Remote ischemic preconditioning has a positive influence on the effects of pneumoperitoneum with $\mathrm{CO} 2$ on the liver, since a significant improvement in the preservation of liver function was observed.

Key words: Pneumoperitoneum. $\mathrm{CO}_{2}$. Repercussion. Liver function. Remote ischemic preconditioning.

\section{RESUMO:}

Objetivo: O objetivo deste estudo foi examinar se o pré-condicionamento isquêmico remoto pode influenciar os efeitos do pneumoperitôneo com $\mathrm{CO} 2$ na função e estrutura do fígado de roedores. Métodos: Foram usados três grupos de 6 ratos cada - Grupo 1: grupo laparotomia; Grupo 2: grupo pneumoperitônio 30 min; Grupo 3: grupo pneumoperitônio 30 min e precondicionamento isquêmico remoto. Duas horas após os procedimentos cirúrgicos foi feita coleta de sangue para dosagem de aspartato aminotransferase (AST), alanina aminotransferase (ALT), e fosfatase alcalina (FA). A eutanásia foi feita com superdose de tiopental (100 mg/kg i.p.). Amostras de tecido hepático foram processadas e coradas com HE. Valores expressos como média desvio padrão foram analisados pelos testes exato de Fisher e de Tukey, com significância $p<0,05$. Resultados: As determinações bioquímicas mostraram níveis significativamente mais altos de ALT, AST e FA nos animais do grupo 2, com valores 74,3 $\pm 3,5,62,3 \pm 3,1$ e $172,6 \pm 3,2$, respectivamente, em comparação com os ratos do grupo 1 - sham, (ALT:

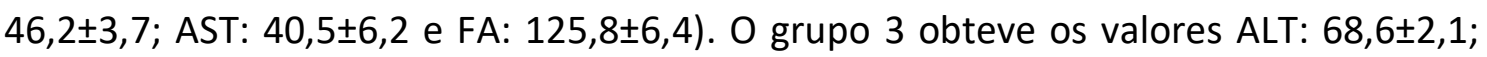
AST: $51,8 \pm 2,7$ e $F A: 144,6 \pm 4,3$ respectivamente, significativamente mais baixos do que no grupo $2(p<0,01)$. Os escores histopatológicos revelaram que no grupo laparotomia (escore 3) os achados de infiltração de neutrófilos, congestão de sinusóides, grau de necrose e vacuolização do citoplasma foram significativamente menos intensos ou ausentes $(p<0,05)$, quando comparados com os grupos pneumoperitônio (escore 6) e pneumoperitônio + I/R remota (escore 5). Apesar do escore do grupo pneumoperitônio + I/R remota ter sido menor do que no grupo pneumoperitônio, a diferença não foi estatisticamente significante $(p>0,05)$. Conclusão: $O$ pré-condicionamento isquêmico remoto tem influência positiva sobre os efeitos do pneumoperitônio com $\mathrm{CO} 2$ no fígado, uma vez que foi observada significativa melhora da preservação da função hepática. 
Effect of remote ischemic preconditioning on hepatic function after $\mathrm{co} 2$ pneumoperitoneum Santos JEF; et al

Palavras-Chave: Pneumoperitônio. CO2. Repercussão. Função hepática. Précondicionamento isquêmico remoto.

\section{INTRODUCTION}

The adverse effects of intra-abdominal hypertension have been reviewed in details ${ }^{1}$. Intra-abdominal pressure was correlated in patients undergoing laparoscopic cholecystectomy (LC) with low blood flow to the liver, measured using a laser Doppler technique. Hepatic microcirculation was significantly reduced during LC performed with a $12 \mathrm{mmHg}$ pneumoperitoneum, indicating splanchnic ischemia ${ }^{2}$. Some studies have shown an increase in the parameters of liver function tests after LC, due to hepatic hypoperfusion and ischemia. It was noticed that, after LC, the serum level of some liver enzymes increases markedly in patients who were in the preoperative with normal dosages ${ }^{3,4}$.

Changes in liver function tests after LC were significant with intra-abdominal pressure maintained at $14-15 \mathrm{mmHg}$, compared to individuals operated after conventional open surgery. During LC, alanine aminotransferase (ALT) doubled in $58.2 \%$ of patients, while doubled in just $6.3 \%$ of patients in the open surgery group ( $p=$ 0.00027 ) after 48 hours. Aspartate aminotransaminase (AST), total bilirubin, alkaline phosphatase (ALP) and serum albumin were altered, but to a lesser extent ${ }^{5}$. The incidental elevation of liver enzymes such as AST and ALT after LC has become a wellknown finding 6,7 .

Carbon dioxide (CO2), a gas used in video surgery, has high blood solubility and can cause hypercapnia and respiratory acidosis. In addition, the intra-abdominal pressure of $12-14 \mathrm{mmHg}$ with $\mathrm{CO} 2$ is able to reduce portal blood flow, causing changes in liver function ${ }^{8,9}$. Everything suggests that free radicals are generated at the end of laparoscopic procedures, possibly as a result of a phenomenon of ischemia and reperfusion induced by pneumoperitoneum insufflation and deflation. Free radicals can damage tissues and organs, especially Kupffer cells and hepatic endothelial sinusoids ${ }^{10,11}$. Since the pneumoperitoneum-induced hepatic hypoperfusion required for laparoscopy has been underestimated, one of the merits of this study is to review the factors that influence hepatosplanknic blood flow during pneumoperitoneum and to alert doctors about the adverse consequences of hypoperfusion in high-risk patients submitted to the procedure ${ }^{12}$.

The phenomenon of remote ischemic preconditioning (RIPC) was demonstrated in a canine model of myocardial infarction, where the preconditioning of a vascular territory at a distance provided protection to the vascular bed of the heart. Other models have been described ${ }^{13}$.

In rats, ischemia of the lower limbs by brief clamping of the abdominal aorta reduced oxidative stress after 45 minutes of renal ischemia in rats ${ }^{14}$. The RIPC of the 
Effect of remote ischemic preconditioning on hepatic function after $\mathrm{co} 2$ pneumoperitoneum Santos JEF; et al

lower limb (which has been shown to be effective for the heart and skeletal muscle) has great clinical advantages, as the limb is easy to manipulate and relatively resistant to ischemia and reperfusion injury. The underlying mechanisms of the RIPC and its signaling pathways remain unclear. Some neurogenic factors and the release of biochemical messengers have been implicated ${ }^{15-17}$.

The aim of this study was to examine whether remote ischemic preconditioning can influence the effects of pneumoperitoneum with $\mathrm{CO} 2$ on the function and structure of liver in rodent.

\section{METHODS}

This study has a descriptive character, of the experience report type, which addresses the experience in the extension project "DYING: A human thing", from the Department of Clinical Medicine at the Federal University of Rio Grande do Norte. The experience was carried out from September to December 2019, with a total workload of 20 hours.

Wistar rats (Rattus norvegicus), 3 to 4 months of age (weight $225 \pm 18 \mathrm{~g}$ ), from the vivarium of the Health Sciences Center of the Federal University of Rio Grande do Norte (UFRN), Brazil, were used. This protocol was submitted to the appreciation and approved by the Ethics Committee on the Use of Animals of the HUOL (CEUA / HUOL) according to the protocol $\mathrm{n}$ - 01/2019. The Wistar rats were kept in individual polypropylene cages with 12 hours light-dark cycles and control of particles and humidity.

First of all the rats went through a 7-day acclimatization period at the Nucleus of Experimental Surgery (Department of Surgery-UFRN), with ad libitum access to water and food for rats (Presence ${ }^{\circledR}$ ). The care in the use of animals followed the Brazilian Legislation for the scientific use of animals (Law no 11.794/2008).

\section{Animals and groups}

The rats were anesthetized with intraperitoneal injection of ketamine $70 \mathrm{mg} / \mathrm{kg}$ and xylazine $7 \mathrm{mg} / \mathrm{kg}$. After epilation and antisepsis of the abdomen with $70 \%$ ethyl alcohol, the pneumoperitoneum or median laparotomy procedure was performed, according to the study groups.

\section{Experimental design}

Eighteen rats were randomly assigned to three groups of 6 rats each.

\section{Group 1: laparotomy group}

In this group rats, after anesthesia and antisepsis of the abdomen with alcohol $70 \%$, a median laparotomy of $3 \mathrm{~cm}$ was performed and the intra-abdominal organs were 
Effect of remote ischemic preconditioning on hepatic function after $\mathrm{co} 2$ pneumoperitoneum Santos JEF; et al

exposed to room air for $30 \mathrm{~min}$. No further manipulation was done. After $30 \mathrm{~min}$, the abdominal wall and the skin were closed with 4-0 nylon suture in two layers.

\section{Group 2: pneumoperitoneum group (30 min)}

In this group, a pneumoperitoneum with $\mathrm{CO} 2$ was performed in anesthetized rats, using a Veress needle connected to a pressurized container. CO2 was inflated using an automatic device (Edlo Ltd, Argentina) until the intra-abdominal pressure reached 10 $\mathrm{mmHg}$. The pneumoperitoneum was maintained at this pressure for $30 \mathrm{~min}$, after which the abdomen was deflated and the needle was removed. All surgical procedures were performed using aseptic technique.

\section{Group 3: pneumoperitoneum group and remote ischemic preconditioning (RIP)}

Immediately before the installation of the pneumoperitoneum, as described above, RIP was induced in animals for short periods of ischemia and reperfusion of the right posterior limb. An elastic tourniquet was used, with pressure greater than blood pressure, around the proximal portion of the animals' thigh in three cycles of $10 \mathrm{~min}$ ischemia/10 min reperfusion. The $10 \mathrm{mmHg}$ pneumoperitoneum was then induced and maintained for $30 \mathrm{~min}$, after which the abdomen was deflated and the Veress needle was removed.

\section{Collection of blood and tissue samples}

Two hours after deflation of the abdomen, blood samples (intracardiac) were collected and centrifuged at $3500 \mathrm{rpm}$ for $10 \mathrm{~min}$ and the serum was stored at $-20^{\circ} \mathrm{C}$ until analysis. The rats were euthanized with overdose of thiopental (100 mg/kg i.p.)

\section{Biochemical analysis}

AST, ALT and ALP in serum were determined using the respective dosage kits (Bioplus 2000 Analyzer, Labtest kits, Brazil) according to the manufacturer's instructions.

\section{Histopathology}

Samples of liver tissue from each animal were collected and fixed in $10 \%$ buffered formaldehyde for 48 hours. After fixation, the liver tissues were sectioned with a thickness of $5 \mathrm{~mm}$ and cut with punch type equipment with a diameter of $06 \mathrm{~mm}$ to standardize the samples. Then, they were treated for 18 hours in an automatic tissue processor, using Leica TP 1020 equipment, Germany. The histological sections were obtained with a Leica RM 2125 RTS microtome, Germany, with a thickness of 03 microns, and mounted on previously silanized slides. The samples were stained using the hematoxylin-eosin ( $\mathrm{H}-\mathrm{E})$ histochemical technique for morphological analysis under an optical microscope. The analysis was performed looking for the following histological findings and using the quantitative criteria presented in Table 1. 
Effect of remote ischemic preconditioning on hepatic function after $\mathrm{co} 2$ pneumoperitoneum Santos JEF; et al

Table 1 - Histological findings and score scores used for histopathological analysis of liver tissue samples.

\begin{tabular}{ll}
\hline \multicolumn{1}{c}{ Histological findings } & \multicolumn{1}{c}{ Scoring and interpretation } \\
\hline Infiltration of neutrophils & 0 - no evidence \\
Sinusoid congestion & 1 - occasional evidence \\
Degree of necrosis & 2 - light \\
Cytoplasm vacuolization & 3 - moderate \\
\hline
\end{tabular}

Source: adapted from Rhoen EL, $2000^{19}$.

\section{Statistical analysis}

All values were expressed as meantstandard deviation. Variables were determined using the Fischer and Tukey $t$ tests. All analyzes were paired and a value of $p<0.05$ was considered statistically significant in all analyzes. Statistical analyzes were performed using the BioEstat, 5.0 software (Belém, PA, Brazil).

\section{RESULTS}

All animals survived the experiments. The classification of the anastomosis according to the graduation previously established in the methodology was not performed due to lack of data, as the presence of abscesses, fistulas and dehiscences in the area of the anastomosis. Macroscopically detectable lesions did not occur in any groups.

All animals survived after the experimental model procedures, and there was no significant difference in body weights, comparing the three study groups ( $p>0.05)$. At the end of the observation period, biochemical determinations showed significantly higher levels of ALT, AST and ALP in animals submitted to pneumoperitoneum with CO2, (group 2) compared to rats in the laparotomy group (group 1) and pneumoperitoneum + ischemia and remote reperfusion (group 3$)(p<0.01)$. These data are summarized in Table 2. 
Effect of remote ischemic preconditioning on hepatic function after $\mathrm{co} 2$ pneumoperitoneum Santos JEF; et al

Table 2. Values of biochemical data and their statistical interpretation.

\begin{tabular}{lcccc} 
Variables & Laparotomy (1) & $\begin{array}{c}\text { Pneumoperitoneum } \\
\text { with CO2 (2) }\end{array}$ & $\begin{array}{c}\text { Pneumoperitoneum } \\
\text { +remote I/R (3) }\end{array}$ & P value \\
\hline ALT (IU/I) & $46.2 \pm 3.7^{*}$ & $74.3 \pm 3.5^{*}$ & $68.6 \pm 2.1^{*}$ & 0.01 \\
AST (IU/I) & $40.5 \pm 6.2^{* *}$ & $62.3 \pm 3.1^{* *}$ & $51.8 \pm 2.7^{* *}$ & 0.01 \\
ALP (IU/I) & $125.8 \pm 6.4 \$$ & $172.6 \pm 3.2 \$$ & $144.6 \pm 4.3 \$$ & 0.01 \\
\hline
\end{tabular}

AST - Aspartate aminotransferase; ALT - Alanine aminotransferase; ASP - Alkaline phosphatase. Data expressed as mean \pm standard deviation. Values on the same line followed by the same symbols mean statistically significant differences. Tukey test.

\section{Histopathology}

Figures 1, 2 and 3 show liver histopathology images of the animals in the 3 study groups. The analysis of the findings transformed by scores revealed that in the laparotomy group 1 the score was 3. Images of neutrophil infiltration, sinusoid congestion, degree of necrosis and vacuolization of the cytoplasm were observed and they were significantly less intense or absent $(p<0.05)$, when compared with the pneumoperitoneum (score 6) and pneumoperitoneum + remote I/R groups (score 5). Although the score in the pneumoperitoneum + remote I/R group was lower than in the pneumoperitoneum group, the difference was not statistically significant. ( $p>0.05)$.
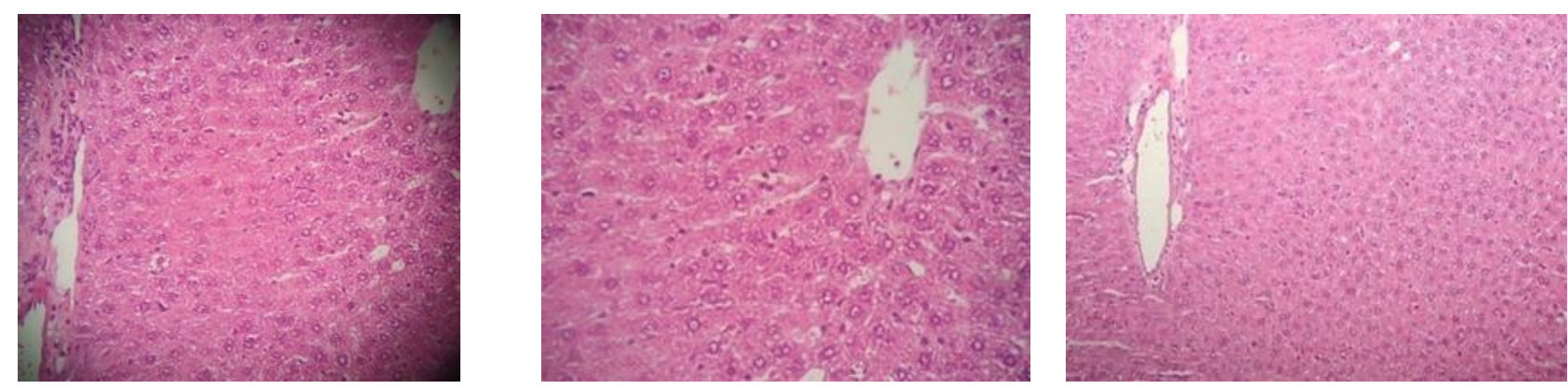

Figure 1: Representative liver histopathology images of animals in the laparotomy group (group 1). H-E.
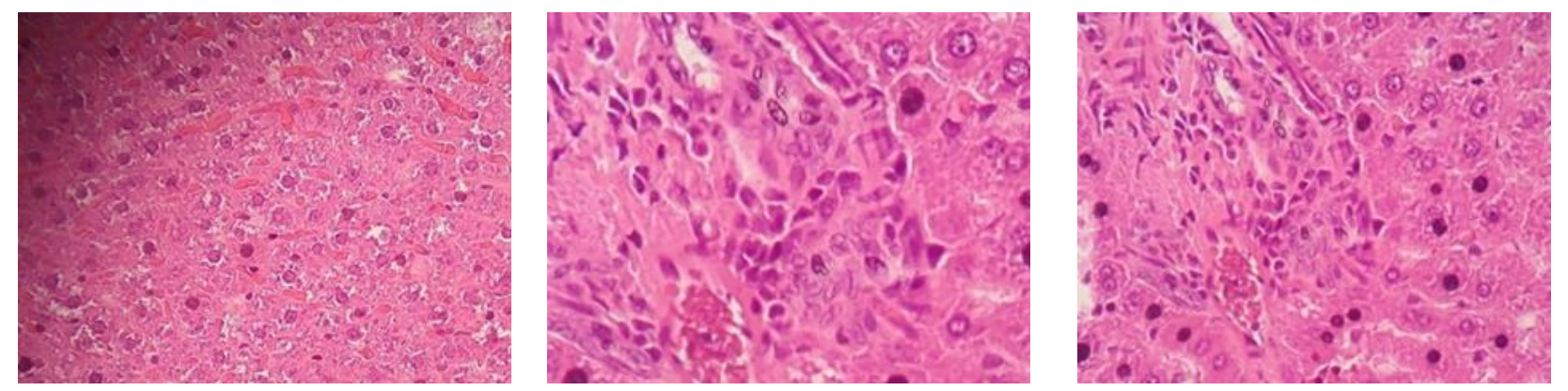

Figure 2: Representative images of histopathology of the liver of animals from the pneumoperitoneum group (group 2). H-E. 
Effect of remote ischemic preconditioning on hepatic function after $\mathrm{co} 2$ pneumoperitoneum

Santos JEF; et al
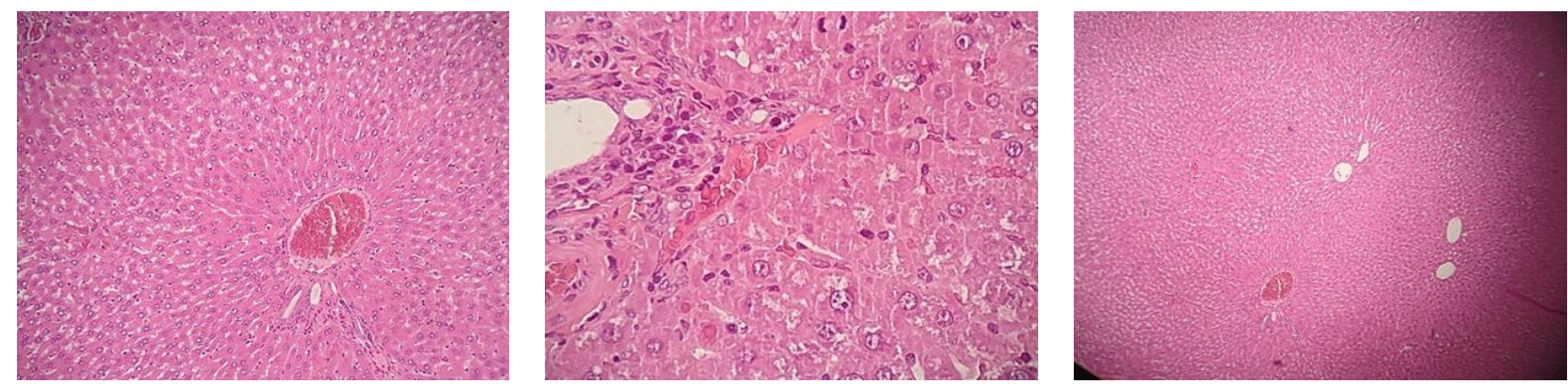

Figure 3: Representative images of histopathology of the liver of animals from the pneumoperitoneum group + remote ischemia/reperfusion (group 3). H-E.

\section{DISCUSSION}

ALT, AST and ALP are classic markers of hepatocellular lesions and are commonly used in clinical and experimental studies to indicate liver injury. In the present study, the biochemical determination of ALT, AST and ALP indicated a higher impairment in liver function in group 2 rats submitted to pneumoperitoneum with $\mathrm{CO} 2$, compared with the other groups. The lowest values were observed in group 1, which had only laparotomy as a procedure, indicating that pneumoperitoneum with $\mathrm{CO} 2$ was responsible for the elevation of liver biochemical markers.

A study with rats found that pneumoperitoneum with $\mathrm{CO} 2$ can induce liver damage. ALT and AST were 101.4 $\pm 9.3 \mathrm{IU} / \mathrm{L}$ and $106.6 \pm 8.7 \mathrm{IU} / \mathrm{L}$, respectively, in the group of rats with pneumoperitoneum induced for one hour18. These results were superior to that found in group 2 (pneumoperitoneum) of the present study. This higher value could be due to the time of pneumoperitoneum to which the rats were submitted, being twice the time used in our study.

Elevation of AST and ALT was also observed in a study with 128 patients who underwent laparoscopic cholecystectomy. However, there was no significant elevation in $\mathrm{ALP}^{19}$. Such findings reinforce that there are probable mechanisms of liver damage during pneumoperitoneum, which include anoxia, ischemia-reperfusion and oxidative stress.

In our study, group 3 (pneumoperitoneum + remote ischemia reperfusion) had significantly reduced values in liver enzymes compared to group 2 , showing that remote ischemic preconditioning can influence the effects of $\mathrm{CO} 2$ pneumoperitoneum on liver function assessed by biochemical markers. A study that evaluated the hepatoprotective effect of remote ischemic preconditioning during human liver resections found significant reductions in serum levels of liver transaminases and bilirubin. In this study, preconditioning was performed with a tourniquet on the right upper limb, with 3 cycles of 5 minutes of ischemia followed by 5 minutes of reperfusion. The work suggests that the hepatoprotective effect is due to the reduction of cytokine release and activation of neutrophils, which decrease endothelial injury, in addition to the increase in vasoactive molecules, such as nitric oxide (NO), and activation of heat shock proteins that inhibit 
Effect of remote ischemic preconditioning on hepatic function after $\mathrm{co} 2$ pneumoperitoneum Santos JEF; et al

apoptosis $^{20}$. Further investigations about the role of these molecules and mechanisms in animal models of remote ischemic preconditioning are needed.

Study of Choi et al (2020) assessed the effect of remote ischemic preconditioning on liver ischemia-reperfusion injury in rats. They found reduced values of AST and ALT compared to the control group. Ischemic preconditioning was induced by 3 cycles of ischemia/reperfusion, performing repeated occlusion/opening (10 $\mathrm{min} / 10 \mathrm{~min}$ ) of the unilateral femoral vascular bundle through a cuff inflator, $30 \mathrm{~min}$ before liver ischemia ${ }^{21}$, similar to the procedure performed in present study.

As for the histopathological analysis in the present study, significant differences were found between group 1 (laparotomy) and groups 2 and 3, submitted to pneumoperitoneum. In group 1, mild sinusoidal congestion and occasional plasma vacuolization were observed, obtaining a score 3. In group 2 (pneumoperitoneum), there was neutrophilic infiltration of occasional evidence, moderate sinusoidal congestion and vacuolization of the cytoplasm, scoring 6 . The group 3 , in which remote ischemic preconditioning was induced before pneumoperitoneum, presented results similar to group 2, with milder sinusoidal congestion, scoring 5 and therefore, having no statistically significant difference. Neutrophilic infiltration in the groups that had pneumoperitoneum as a procedure was expected, since local and systemic injuries caused by ischemia and reperfusion are associated with the accumulation of neutrophils in the microvessels ${ }^{22}$.

The histopathological findings are similar to those observed in studies that evaluated the effect of remote ischemic preconditioning on models of ischemia and reperfusion injury in the hepatic microcirculation of rats. These studies found sinusoidal congestion and significant necrosis in the groups submitted to ischemia-reperfusion injury. In the groups that performed remote ischemic preconditioning, less necrosis and liver damage were observed, but without statistical significance ${ }^{23,24}$. In none of the groups in the present study, the presence of liver necrosis was observed, showing that the induced pneumoperitoneum was not sufficient to cause tissue damage to the point of necrotizing liver tissue.

\section{CONCLUSION}

Remote ischemic preconditioning positively influences the effects of pneumoperitoneum with $\mathrm{CO} 2$, as an improvement was observed in the preservation of liver function. Further investigation of the mechanisms involved in the hepatoprotective effect is required, in addition to research with protocols adapted to the clinical setting. 
Effect of remote ischemic preconditioning on hepatic function after $\mathrm{co} 2$ pneumoperitoneum Santos JEF; et al

\section{REFERENCES}

1. Gupta R, Kaman L, Dahiya D, et al. Effects of varying intraperitoneal pressure on liver function tests during laparoscopic cholecystectomy. J Laparoendosc Adv Surg Tech A. 2013;23:339-42.

2. Avraamidou A, Marinis A, Asonitis $S$, et al. The impact of ischemic preconditioning on hemodynamic, biochemical and inflammatory alterations induced by intraabdominal hypertension: an experimental study in a porcine model. Langenbecks Arch Surg. 2012;397:1333-41.

3. Al-Luwaizia KR, Hamad SO. Changes of liver enzymes and serum bilirubin after laparoscopic cholecystectomy. Ann Coll Med Mosul. 2013;39:113-17.

4. Koirala R, Shakya VC, Khania S, et al. Rise in liver enzymes after laproscopic cholecystectomy: a transient phenomenon. Nepal Med Coll J. 2012;14:223-6.

5. Saber AA, Laraja RD, Nalbandian $\mathrm{HI}$, et al. Changes in liver function tests after laparoscopic cholecystectomy: not so rare, not always ominous. Am Surg. 2000;66:699-702.

6. Hagras MA. Alterations in liver function tests following laparoscopic. Pak J Surg 2013;29:245-47.

7. Krupalija A, Durić A, Pandža $H$, et al. The effect of pneumoperitoneum on biochemical liver functions in acute cholecystitis. BH Surgery. 2012;2:25-34.

8. Eryılmaz HB, Memiş $D$, Sezer A, et al. The effects of different insufflation pressures on liver functions accessed with limon on patients undergoing laparoscopic cholecystectomy. Sci World J. 2012;2012:172575.

9. Glantzounis GK, Tselepis AD, Tambaki AP, et al. Laparoscopic surgery-induced changes in oxidative stress markers in human plasma. Surg Endosc. 2001;15:13159.

10. Cekic B, Geze S, Ozkan G, et al. The effect of dexmedetomidine on oxidative stress during pneumoperitoneum. Biomed Res Int. 2014;14:760323.

11. Tauro LF, Sheethal CM, Aithala PS, et al. Evaluation of Effects of Laparoscopic Surgery on Hepatic Function. J Clin Diagn Res 2008;2:1155.

12. Hasukic S. CO2-Pneumoperitoneum in Laparoscopic surgery: Pathophysiological effects and clinical significance. World J Laparosc Surg. 2014;7:33-40.

13. Atesx E, Gencx E, Erkasap N et al. Renal protection by brief liver ischemia in rats. Transplantation. 2002; 74: 1247-51.

14. Lazaris AM, Maheras AN, Vasdekis SN et al. Protective effect of remote ischemic preconditioning in renal ischemia/reperfusion injury in a model of thoracoabdominal aorta approach. J Surg Res. 2009;154:267-73.

15. Loukogeorgakis SP, Panagiotidou AT, Yellon DM et al. Postconditioning protects against endothelial ischemia-reperfusion injury in the human forearm. Circulation. 2006;113:1015-19. 
Effect of remote ischemic preconditioning on hepatic function after $\mathrm{co} 2$ pneumoperitoneum Santos JEF; et al

16. Hausenloy DJ, Yellon DM. Preconditioning and postconditioning: underlying mechanisms and clinical application. Atherosclerosis. 2009;204:334-41.

17. Tapuria N, Kumar $\mathrm{Y}, \mathrm{Habib} \mathrm{MM}$ et al. Remote ischemic preconditioning: a novel protective method from ischemia reperfusion injury-a review. J Surg Res. 2008;150:304-30.

18. Xu GS, Liu HN, Li J, Wu XL, Dai XM, Liu YH. Hepatic injury induced by carbon dioxide pneumoperitoneum in experimental rats. World J Gastroenterol. 2009;15(24):30604.

19. Rhoden EL, Pereira-Lima L, Rhoden CR, et al. Analysis of the histopathologic alterations of the livers in rats pretreated with allopurinol and submitted to hepatic ischemia: reperfusion. Rev Col Bras Cir. 2000;27:373-7.

20. Rakić M, Patrlj L, Amić F, et al. Comparison of hepatoprotective effect from ischemia-reperfusion injury of remote ischemic preconditioning of the liver vs local ischemic preconditioning of the liver during human liver resections. Int J Surg. 2018;54:248-253.

21. Choi EK, Jung $\mathrm{H}$, Jeon $\mathrm{S}$, et al. Role of Remote Ischemic Preconditioning in Hepatic Ischemic Reperfusion Injury. Dose Resp. 2020;18(3):1-6.

22. Miranda LEC, et al . As bases experimentais da lesão por isquemia e reperfusão do fígado: revisão. Acta Cir Bras. 2004;19:1-12.

23. Tapuria N, Junnarkar SP, Dutt N, et. al. Effect of remote ischemic preconditioning on hepatic microcirculation and function in a rat model of hepatic ischemia reperfusion injury. HBP (Oxford). 2009;11:108-117.

24. Guimarães-Filho MAC. Efeito do pré-condicionamento isquêmico remoto em modelo de lesão hepática por isquemia-reperfusão em ratos. Dissertação de Mestrado, UERJ. 2013. $90 \mathrm{f}$. 